\title{
Psychosocial Effects Of News Channels On The Female Youth In The Contemporary Society
}

\author{
Sumera Ishrat \\ Department of Social work \\ University of Karachi
}

\begin{abstract}
The present study aimed to investigate extend of watching News Channels in everyday routine of the female youth and explore the effects of these channels on their psychological state as well as their social life in our society. Multistage Sampling technique was adopted in this research. Questionnaire was used to collect data from the female youth studying in University of Karachi. The sample consisted of 120 purposively selected respondents. The findings of the study indicated that in present law and order scenario of our city the females watch news channels regularly. They criticize the present trend of news telecasting, live scenes from incidents sites and screening of related details. They acclaimed that the current strategy of news channels have promoted fear, in-tolerance, helplessness, disappointment and depression among them. As far as social impacts are concerned these channels disturbed not only the social life but also created disorganization in the social system as a whole. The study concluded that Media Industry should review its News casting policies and revise the strategies on war footing. Government authority should maintain a check upon the media specifically on the performance of News Channels. Along with this, awareness sessions must be held at educational institutes and professional organizations which inform the viewers (students and professionals) to analyze reliability and validity of the news.
\end{abstract}

Keywords: Psychosocial effects, News Channels, Female Youth, Society.

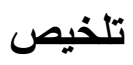

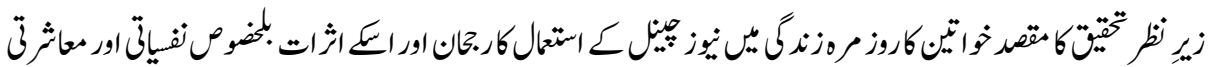

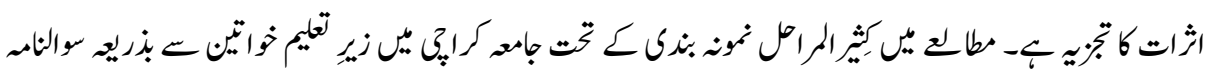

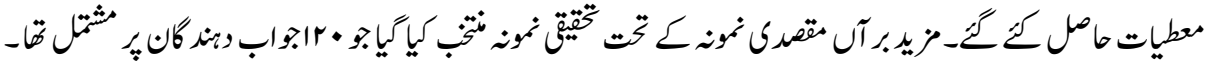

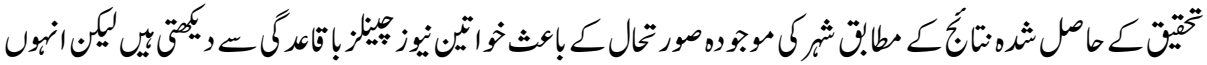

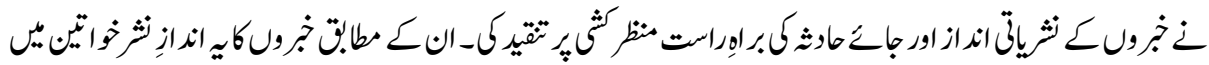

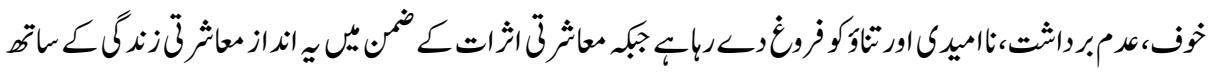

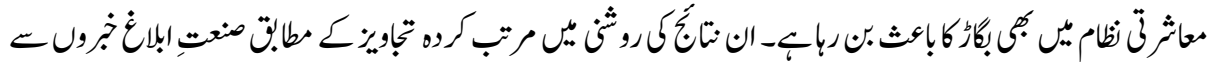

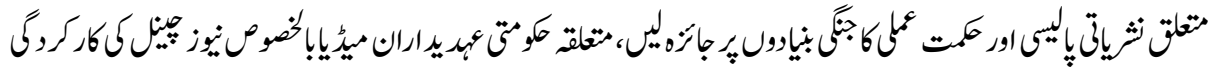




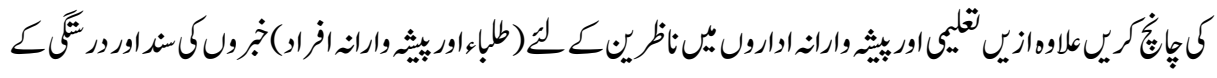

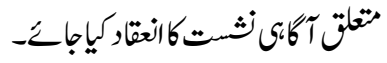

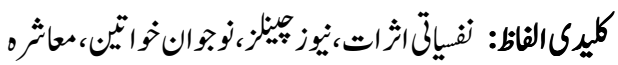

\section{Introduction}

Media plays a vital role in providing information, education and entertainment to the population. Today, the world is known as a global village as information is spread effortlessly and is easily accessible.

Khan, et.al. (2013) marked that Mass media has emerged as a huge source of entertainment and specially information from last two decades. Some studies conducted by UNDP show that there is a direct relationship between socio economic development of the country and the level of development of its mass media. The media relationship with the society is both reflexive the mass media simultaneously affects and affected by mass society. Media is more powerful than nuclear devices, said Jawad Jabbar Ex. employee PEMRA. Scope of Electronic media is larger than print or social media, as its audience even includes illiterate people.

With the start of 21st century television has become an important factor for every home and now it is difficult to imagine life without television. Television is not only considered for entertainment but it is also an important source of information and provides different kinds of program carrying variety range of social issues. Over the last two decades the number of television sets in the both developing as well as developed world has been increased extraordinary. Different studies shown that since from 1980 the number of television sets in Asia has been increased more than six times, from hundred million to six fifty million.

Television systems are planned for transmission as a conceptual process. The pattern of distribution of television media has been centre - periphery and due to its popularity in society it become the power centres of society. Second important attribute of television is the sense of familiarity and personal association that it seems able to cultivate between the watcher and anchor or the actors and participants on screen. Actually television is considered as the primarily source of entertainment but no one can denied from its important role in today politics and it is also considered the main channel of communication between politicians and citizens especially at election era. (McQuail, 2005). 
Qaiser, et.al, (2014) stated that in developed world average persons spend nearly twenty hours per week in front of television which mean that a man spend nearly nine years in front of the television during his whole life. For example in developed world adult watches television three to four hour daily while majority of the youth (ages 2-17) watched television nearly 20 hours per week. This high exposure of television shows that it is the main source of knowledge for general public. Due to television the life pattern of people has dramatically changed and in this modern world, we cannot imagine without it. It is also important feature of television that we can get many information and gratification from it and without it our life will become bore and fed up. The information which we get from the genres of television also told us about the perception of people regarding political parties and their leaders. Along with its positive effects television has also lot of negative effects. Due to this it takes away peoples from other activities, such as social interaction with their families, friends and also avoid from other co curricular activities. In spite of this it also become the source of violence, in our society. Studies also showed that those people who watched television more, their views were also more related to the televised picture as compared to those who watched television rarely.

The role of mass media in Pakistani society is tri-dimensional that is informing the public, educating the unknowledgeable and providing entertainment. A survey conducted by Gilani Research Foundation, which carried out by Gallup Pakistan revealed that more than half $(52 \%)$ of all Pakistanis consider media to be a source of awareness, while $29 \%$ believed otherwise.

In Pakistan during November 26, 1964 the first official television station commenced transmission broadcasts from Lahore, followed by Dhaka in 1965 (then the capital of East Pakistan). A third centre was established in Rawalpindi-Islamabad in 1965 and the fourth in Karachi in 1966. Later centres in Peshawar and Quetta were established by 1974 . We now have 90 TV channels besides 28 foreign channels for Pakistani audience.

In the present era people rely on News media specifically on News Channels as major source of information regarding National and International scenario. They also consider as the most important channels for the propagation of culture, ideas and opinion at the same time. Opinion formation takes place when people sit and watch News and debates on television programmes.

Infusion and diffusion of news in Pakistan is not satisfied because of ineffectual reporting in different situations. Infusion is the process of collecting, selecting and interpreting news from different areas with the help of different sources, which include the correspondents or interpersonal communication or government authorities, while diffusion of news is the process of dissemination and circulation of news through mass media. Pakistani media is also collecting terrorism news from different sources like 
correspondents, interpersonal communication and also getting news and footage from a layman of the society (Paracha: 2013).

Shamsi (2005), in his book Journalism ethics and code says that every news story should be clear and fair to find out what really happened, because sometimes the story creates doubts in the minds of readers, listeners and viewers and consider as a subjective news. He further said that inventing information is mostly wrong and dangerous, not only for media organization but also for the nation and country. He has explained the term objectivity that news must be reported with complete objective manner, without any distortion. Don't mix news and views about an event which create ambiguity among the public. He also viewed that journalist should perform social responsibility to provide truthful, comprehensive and factual report about an event, and not to expend panic and terror among the audience. He further said that like other citizens, journalist is served by all the law of land. He claimed that journalist should present their information in a fair, accurate and unbiased manner. The news should be verified before publication, telecasting and broadcasting. He supported the point that it is also moral and ethical part of the journalist to correct all the errors from his /her report and avoid exaggerated and sensational heading and news story.

A research study (1997) entitled "The psychological effects of viewing negative news items" concluded negative news likely to make you sadder and more anxious; they are also like to exacerbate their own personal worries and anxieties. It was expected that news item reflecting war, famine and poverty might induce viewers to ruminate on such topics. But the effects of negative news are much broader than that - it can potentially exacerbate a range of personal concerns of specifically relevant to the contents of the programmes itself. So, bombarding people with 'sensationalize' negativity does have genuine and real psychological effects (Graham, 2012)

Inspite all the above mentioned facts it has been proven in present situation female is the most vulnerable segment of society which being sensitive their domestic/family, psychological and social life is badly affected and their activities are also changed. Like all they are depended on News channels for update information. The trends of these channels as already discussed have spread hopelessness, fear, confusion and sense of unsecurity in the environment. Being sensitive they got disturbed, depressed, annoyed and their social gatherings are also badly affected. Therefore overall the society is facing negative effects due to extensive exposure to news.

This research study will highlight the effects of watching News channels which are causing harm to psychosocial life of female youth in our society. It is the most ignored aspect of modern day researches in social sciences. The results of present study will be helpful to the concern organizations (public/private) to review their media policies, trend 
of news telecasting and programme formatting. As well as motivate social scientists to conduct more relevant researches, suggest immediate remedies, result oriented long-term strategies and practical alternatives in this regards.

\section{Objectives}

The following objectives were drawn for this study:

1. To explore extend of utilizing news channels in daily life of female youth.

2. To investigate how the News channels have changed the social life of female youth.

3. To examine the nature of psychological effects of News channels on female youth.

4. To study the level of awareness regarding the psychological changes occurred in the personality and routine life of female youth.

\section{Methodology}

In the present study the data was collected from eight departments in the Faculty of Social Sciences, University of Karachi by adopting Systematic sampling technique. The Sample included Female youth which was selected through purposive sampling method. The Sample size of the study consisted on 120 female students from the sampled departments.

A Tailor-made pretested and self-administered Questionnaire was used as the research tool for data collection. It was divided into three sections. First section contained items related to the socio-demographic information, the second section dealt with the family profile of respondents while the third section focused on the trends of watching news channels in daily routine, the extend of depending on broadcasted information as well as the influences of these channels specifically psychosocial influences on the life of respondents. Overall the research instrument contained 45 items.

The respondents were fully informed about the research objectives and their inclusion was made on their consent. Lastly, the data analysis was manually done and presented in frequency distribution tables. 


\section{Findings of the Study}

Table: 1

Distribution of respondents according to their age

\begin{tabular}{|l|c|c|}
\hline Age (Years) & Frequency & Percentage \\
\hline $18-20$ & 42 & $35 \%$ \\
\hline $21-23$ & 56 & $47 \%$ \\
\hline $24 \&$ above & 22 & $18 \%$ \\
\hline Total & $\mathbf{1 2 0}$ & $\mathbf{1 0 0 \%}$ \\
\hline
\end{tabular}

Most of the respondents (47\%) belong to $21-23$ years of age group, $35 \%$ belong to $18-$ 20 years while the age of $18 \%$ of the respondents is 24 years and above.

Table: 2

Distribution of respondents according to the most watched news channels

\begin{tabular}{|l|c|c|}
\hline News Channels & Frequency & Percentage \\
\hline PTV News & 6 & $5 \%$ \\
\hline GEO News & 58 & $49 \%$ \\
\hline Express News & 17 & $14 \%$ \\
\hline Samaa & 16 & $13 \%$ \\
\hline Duniya News & 6 & $5 \%$ \\
\hline CNBC & 4 & $3 \%$ \\
\hline Dawn News & 7 & $6 \%$ \\
\hline Other & 6 & $5 \%$ \\
\hline Total & 120 & $100 \%$ \\
\hline
\end{tabular}

Majority of the respondents (49\%) claimed that they watched GEO News, 14\% Express News, 13\% Samaa, 5\% PTV News, Duniya News and others, 6\% Dawn News while few respondents $(3 \%)$ CNBC.

Table: 2.1

Distribution of respondents according to the reason of watching this news channel

\begin{tabular}{|l|c|c|}
\hline Causes & Frequency & Percentage \\
\hline prompt news telecasting & 65 & $54 \%$ \\
\hline doesn't promote sensation & 31 & $26 \%$ \\
\hline reliable news telecasting & 24 & $20 \%$ \\
\hline Total & 120 & $100 \%$ \\
\hline
\end{tabular}


Majority of the respondents $(54 \%)$ claimed that the most watched news channel telecast news immediately while $26 \%$ respondents said it doesn't promote sensation in the society and $20 \%$ marked that it telecast reliable news.

Table: 3

Distribution of respondents according to their opinion that news channels are the best source of keeping the society informed

\begin{tabular}{|l|c|c|}
\hline Best source of information & Frequency & Percentage \\
\hline Yes & 103 & $86 \%$ \\
\hline No & 17 & $14 \%$ \\
\hline Total & 120 & $100 \%$ \\
\hline
\end{tabular}

A huge majority of the respondents (86\%) admitted that News channels are the best source of keeping the society informed while only $14 \%$ did not agree with this.

Table: 4

Distribution of respondents as they think that news channels transmitting sociocultural values

\begin{tabular}{|l|c|c|}
\hline Transmitting socio-cultural values & Frequency & Percentage \\
\hline Yes & 48 & $40 \%$ \\
\hline No & 72 & $60 \%$ \\
\hline Total & 120 & $100 \%$ \\
\hline
\end{tabular}

Mostly the respondents $(60 \%)$ claimed that News channels are not transmitting sociocultural values in the society but $40 \%$ of the respondents believe it as a source of transmission of the socio-cultural values.

Table: 5

Distribution of respondents according to their opinion as news channels portray national emotions

\begin{tabular}{|l|c|c|}
\hline Portraying national emotions & Frequency & Percentage \\
\hline Yes & 71 & $59 \%$ \\
\hline No & 49 & $41 \%$ \\
\hline Total & $\mathbf{1 2 0}$ & $\mathbf{1 0 0 \%}$ \\
\hline
\end{tabular}

Majority of the respondents $(59 \%)$ are in favour that News channels portray National emotions while $41 \%$ don't agree with the statement. 
Table: 6

Distribution of respondents as news channels playing a positive role in shaping the mindset of the society

\begin{tabular}{|l|c|c|}
\hline Positive role in shaping the mindset & Frequency & Percentage \\
\hline Yes & 52 & $43 \%$ \\
\hline No & 68 & $57 \%$ \\
\hline Total & $\mathbf{1 2 0}$ & $\mathbf{1 0 0 \%}$ \\
\hline
\end{tabular}

Most of the respondents (57\%) don't agree that News channels playing a positive role in shaping the mindset of the society while $43 \%$ of the respondents don't agree with the statement.

Table: 7

Distribution of respondents according to the psycho-social influences of news channels on the youth

\begin{tabular}{|l|c|c|c|c|c|c|}
\hline $\begin{array}{l}\text { Psychological } \\
\text { influences }\end{array}$ & \multicolumn{2}{|c|}{ Yes } & \multicolumn{2}{c|}{ No } & \multicolumn{2}{c|}{ Total } \\
\hline & Frequency & Percentage & Frequency & Percentage & Frequency & Percentage \\
\hline Thinking & 96 & $80 \%$ & 24 & $20 \%$ & 120 & $100 \%$ \\
\hline $\begin{array}{l}\text { Sensitizing the } \\
\text { emotions }\end{array}$ & 101 & $84 \%$ & 19 & $16 \%$ & 120 & $100 \%$ \\
\hline $\begin{array}{l}\text { Promotion of } \\
\text { fear }\end{array}$ & 78 & $65 \%$ & 42 & $35 \%$ & 120 & $100 \%$ \\
\hline $\begin{array}{l}\text { Effect } \\
\text { tolerance } \\
\text { ability }\end{array}$ & 93 & $78 \%$ & 27 & $22 \%$ & 120 & $100 \%$ \\
\hline Social influences & & $75 \%$ & 30 & $25 \%$ & 120 & $100 \%$ \\
\hline $\begin{array}{l}\text { Raise the } \\
\text { crime rate }\end{array}$ & 90 & $79 \%$ & 25 & $21 \%$ & 120 & $100 \%$ \\
\hline $\begin{array}{l}\text { Effect } \\
\text { educational } \\
\text { activities }\end{array}$ & 95 & $86 \%$ & 17 & $14 \%$ & 120 & $100 \%$ \\
\hline $\begin{array}{l}\text { Daily routine } \\
\text { life }\end{array}$ & 103 & & & & & \\
\hline
\end{tabular}

The above is a consolidated table which reflects the psycho-social influences on youth. As far as the Psychological effects are concern the respondents marked that News channels are affecting their thinking (80\%), sensitizing the emotions (84\%), promoting fear $(65 \%)$ and affecting the tolerance ability of our youth. While the respondents identified the social influences of these channels at the same time, they identified that News channels have raised the crime rate $(90 \%)$, affect the educational activities $(95 \%)$ and their routine life (103\%) as a whole. 
Table: 8

Distribution of respondents according to their opinion that news channels bring social change

\begin{tabular}{|l|c|c|}
\hline Bring social change & Frequency & Percentage \\
\hline Yes & 65 & $54 \%$ \\
\hline No & 55 & $46 \%$ \\
\hline Total & $\mathbf{1 2 0}$ & $\mathbf{1 0 0 \%}$ \\
\hline
\end{tabular}

Majority of the respondents claimed that News Channels bring social change while 55\% of them don't identify these channels as a factor of social change.

Table: 8.1

Distribution of respondents according to the nature of social changes

\begin{tabular}{|l|c|c|}
\hline Nature of social changes & Frequency & Percentage \\
\hline $\begin{array}{l}\text { Reduces the trend of family } \\
\text { gatherings }\end{array}$ & 16 & $25 \%$ \\
\hline Reduces recreational activities & 15 & $23 \%$ \\
\hline $\begin{array}{l}\text { Created hurdles in day to day } \\
\text { activities }\end{array}$ & 31 & $48 \%$ \\
\hline All of the above & 3 & $4 \%$ \\
\hline Total & $\mathbf{6 5}$ & $\mathbf{1 0 0 \%}$ \\
\hline
\end{tabular}

The above is a subsidiary table of the Table No. 8 which highlighted the nature of social change caused by the News Channels. Mostly the respondents (48\%) pointed out that News channels have created hurdles in day to day activities, $25 \%$ claimed that these reduced the trend of gatherings among families, $23 \%$ believed that they have reduced the recreational activities while $3 \%$ of the respondents agree with all the mentioned social changes.

\section{Discussions}

The findings of the present study show that youth especially female youth is very conscious about National and International political happenings as well as social scenario. Along with this, they are well aware about the events and incidents in their surroundings. They also have a critical eye on today's media specifically status of News channels.

Most of the respondents (57\%) belong to joint family system and their families comprised of 8 - 10 members. These respondents have trend of watching News Channels regularly. Majority $(86 \%)$ admit that these channels are the most effective source of information in today's world. 
Inspite the responses related to the utility of News channels. The findings marked that due to intense exposure to international media they can give an indepth comparative analysis of the status of News channels from national and international perspective. According to them our News channels are far behind from the international standards.

Most of the respondents strongly believed that professionalism regarding news telecasting is the missing element in Pakistani media. News channels are not guiding the masses towards the solutions or alternatives in current political and social circumstances but they are creating chaos, confusion and social disorganization.

Psychologically speaking, $80 \%$ of the respondents firmly believed that youth psyche has been affected by these channels. Huge majority (84\%) agreed that news channels have made the youth emotionally sensitized, $78 \%$ indicated that the tolerance level have weaken, and $65 \%$ indentified the promotion of fear. Repeat telecast of 'Breaking News' is psychologically disturbing for the viewers.

Mostly (79\%) of the respondents claimed that their educational activities, social gatherings and recreational opportunities have minimized.

After a thorough analysis of the research findings it has been concluded that in the present age Female youth in Pakistani society rely on news telecasted by channels and plan their daily activities accordingly. Meanwhile, they got confused, scared and depressed due to the current trend of telecasting Breaking News and live scenes from incident sites. As the resultant, their social life changed in all respect. On the other hand, this media practice promoted various negative elements in their personalities.

\section{Conclusions}

In the present time, information and technology are interwoven with the society's economic progress. Media is considered as the fourth pillar of a state throughout the world. However, with this growing significance also comes greater responsibility on media. It can give directions to social change and guide the society towards the desired goals in positive manner.

The electronic media may be successful stimulating the change in tightly held ideas and rigid behaviours. Mobilization of public opinion in support of a cause is the known feature of the electronic media in Pakistan. The media to some extend enabled the viewers to be critical viewers with the help of penal discussion programmes, talk shows and few morning shows where progressive discussion took place. 
Besides all this the objectivity of media is becoming a question mark. The coverage of issues of National interest demand care and restraint. But the Pakistani media, News channels specifically are devoid of objectivity and just telecast such incidents that sometimes are not factual. In order to improve their ratings and enhance viewership, the tool of sensationalism is frequently used. As the resultant, it has taken hope from the public and has made them over sensitive regarding their surroundings.

People remained fixed to TV screen at the cost of their social life. They have cut-short their social activities just to watch news, talk shows and other relevant programmes. They are not giving time to their kids, parents and siblings which developed generation gap.

It is known for a long time that content of a film or television programmes (dramas/news) can affect psychological health. It can be done by directly affecting the mood and various aspects of person's thinking and behaviours. The TV programmes generates negative mood experiences (e.g anxiety, sadness, anger, disgust) then these experiences will affect how one interprets in his/her life.

Nowadays, News bulletin have to compete with entertainment programmes for their audience and for their prime-time TV slot, and seems to do this by emphasizing emotionally relevant material such as crime, war, famine etc, at the expense of more positive contents.

The individual and organizations (public/private) concern must remember that our society is in transition so the electronic media should help to develop a harmonious society, bridge gap between reality and the distortion. The media should project objective analysis of the events. Specifically News Channels should present the events by avoiding biases, prejudices and negative perception of various groups operating in the society.

\section{Recommendations}

In the light of the findings of present study it is the need of time to streamline current media policies and implement result oriented strategies to cope prevailed negativity among our youth and minimize harmful psychosocial effects. In this regard, recommendations are underlined:

News media should review the direction of their work. Their programmes must promote patriotism, zeal and enthusiasm among the youth.

News Channels along with information should also provide good cultural values, educational and awareness programmes related to different aspects of life.

It should practise censorship while showing scenes consisting of violence, bomb blast, natural disaster, accidents and other disturbing events. 
A code of conduct should be followed and discussed with participants of political talk shows prior to on air telecasting.

Success stories of our citizens should be highlighted and practice should be promoted to showcase our Nation as a reputed one amongst international audience.

Breaking News segment should not be used for profitability, panic and trauma creating activities should be restricted.

News channel's industry should hire Professional social workers as Health Managers to ensure the programme contents and their telecasting is socially safe.

Health standards should be made a part of the policy whereas training sessions for media personnel regarding community psychology and social beliefs should be arranged.

Training in teaching sessions is important in educational institutes to watch these channels in an objective way with critical eye to analyze news on the basis of their content's reliability.

Government authorities must bring laws to restrict news channels to sensationalize news and screening of violent scenes.

\section{References}

Graham, C. L. Daveys (2012). The Psychological Effects of T.V News: Negative News on TV is increasing but what are its psychological effects? Published in 'Why We Worry'.

Khan, Amaima Yawar, et. al. (2013). Impacts of Mass Media in Pakistan on Social, Ethical and Economic Grounds, Int. J. Eco. Res., v4i3. 1-20

McQuail, D. (2005). “McQuail’s Mass Communication Theory”. London: Sage

Paracha, Sajjad Ahmad, et. al. (2013).To Analyze the News Contents of Electronic and Print Media in Pakistan, Whether Media is Terrorizing or Informing the community, International Journal of Academic Research in Business and Social Sciences. vol.3:3, pp.59-67

Qaiser, Abdul Rehman. (2014). Effect of Private Television Channels' Current Affairs Program on Students: A Case of University of Sargodha, Scholars WorldIRMJCR. vol.II:IV, pp.67-71.

Shamsi, Nayyar (2005). Journalism: Ethics and Code, Anmol Publication 1td, New Delhi, pp.3-61 


\section{Bibliography}

Bausinger, H. (1984). Media, Technology and Daily Life, Media, Culture and Society, vol.6, pp.343-351.

Bhatti, Muhammad Ahsan. (2014).Psychological effects of TV News Violence on youth: A Case Study of the Students of Bahauddin Zakariya University, Multan Pakistan Journal of Social Sciences (PJSS), vol.34:1

Bryant, J. \& Zillman, D. (eds.). (1986). Perspectives on Media Effects, Hillsdale, N.J.: Erlbaum.

Comstock, G. (1975). Television and Human Behaviour: The key studies. Santa Monica, Cal.: The Rand Corporation.

Eron, L. D., Huesmann, L. R., Lefkowitz, M. M., \& Walder, L. O. (1972). Does Television Violence Cause Aggression? American Psychologist.

Fejes, F. (1984). Critical Mass Communications Research and Media Effects: The Problem of the Disappearing Audience. Media, Culture and Society, vol.6:3, pp.219-232.

Freedman, J. L. (1984). The Effect of Television Violence on Aggressiveness, Psychological Bulletin, vol.96, pp.227-246.

Imtiaz, Fauzia, Ellahi, Noor \& Zaidi, Yawar Hasan (2015) Impact of Media on Social Behavior of Individuals Living in Karachi, International Journal of Endorsing Health Science Research, vol.3:2.

Mahsud, Muhammad Nawaz. (2013). Television Channels' Current Affairs Programs and Students' Gratification: A Case of University of Sargodha. Berkeley Journal of Social Sciences, vol.3

Naz, et. al., (2015). Impact of News Channels on Youth: A Comparative Qualitative Study, International Journal of Innovation and Applied Studies, vol.12:3.

Dr. Sumera Ishrat is Assistant Professor in the Department of Social Work, University of Karachi. 